\title{
FAKTOR - FAKTOR YANG MEMPENGARUHI PRODUKSI DAN PENDAPATAN USAHATANI RUMPUT LAUT (EucheumaCottonii) DI KECAMATAN LIANG KABUPATEN BANGGAI KEPULAUAN
}

\author{
Heny Ariwijaya \\ Dosen Fakultas Ekonomi Universitas Tompotika Luwuk
}

\begin{abstract}
ABSTRAK
Faktor-faktor yang Mempengaruhi Produksi Dan Pendapatan Usahatani Rumput Laut di Kecamatan Liang Kabupaten Banggai Kepulauan . Penelitian ini bertujuan untuk : (1) mengetahui pengaruh bibit, tenaga kerja, luas lahan, dan pengalaman terhadap produksi rumput laut kering di Kecamatan Liang Kabupaten Banggai Kepulauan.(2) mengetahui seberapa besar pendapatan petani rumput laut di Kecamatan Liang Kabupaten Banggai Kepulauan. Penentuan sampel di lakukan dengan metode propotional random sampling, yaitu dengan dihitung berdasarkan perbandingan, dalam hal ini perbandingan jumlah populasi pada objek yang diteliti. Analisis data yang digunakan adalah Analisis faktor produksi CobbDouglas dan Analisis Pendapatan. Hasil Penelitian menunjukan bahwa input produksi bibit $\left(\mathrm{X}_{1}\right)$, tenaga kerja $\left(\mathrm{X}_{2}\right)$ dan luas lahan $\left(\mathrm{X}_{3}\right)$ berpengaruh sangat nyata pada taraf kepercayaan $99 \%$ terhadap produksi rumput laut kering (Y), sedangkan variabel pengalaman $\left(\mathrm{X}_{4}\right)$ berpengaruh tidak nyata terhadap produksi kering rumput laut (Y). Pendapatan rata-rata petani rumput laut dalam satu kali musim tanam dilokasi penelitian sebesar Rp. 2.164.509 .- . Kata Kunci : Rumput Laut, Usahatani, Cobb-Douglas, Produksi dan Pendapatan
\end{abstract}

\section{PENDAHULUAN}

Rumput laut merupakan salah satu sumber devisa Negara dan sumber pendapatan bagi masyarakat daerah pantai. Wilayah Indonesia yang sebagian besar berupa laut (70 \%) merupakan Negara yang kaya rumput laut dan memiliki usaha pembudidayaan rumput laut yang cukup menjanjikan karena kebutuhannya setiap tahun semakin meningkat. Produksi rumput laut yang berlimpah ini setiap tahun diekspor dan sebagian digunakan untuk kebutuhan dalam negeri.

Komoditi rumput laut merupakan salah satu komoditi andalan sektor perikanan dan kelautan yang sangat strategis untuk dikembangkan. Dianggap strategis karena di samping masa tanamnya yang relative singkat, yaitu kurang lebih 2 bulan, komoditi ini juga menyerap tenaga kerja yang cukup banyak dan juga pasar lokal dan regional yang menjanjikan serta harga jual yang cukup kompetitif. Menurut International Corporation (IFC) World Bank Group (2007) yang dikutip oleh Keppel (2008) total produksi karaginofit (rumput laut penghasil karaginan) dan saat ini masih dibutuhkan sekitar 30.000 50.000 ton, dengan peningkatan permintaan dunia sebesar 5-10\% pertahun. Sementara itu, kebutuhan pasar karaginan untuk berbagai aplikasi secara total adalah 33.000 ton yang digunakan untuk perusahaan susu 11.000 ton (33\%), daging dan unggas 5.000 ton (15\%), gel air 5.000 (15\%),PES grade food 8.000 ton (25\%), odol 2.000 ton (6\%), lainnya 2.000 ton $(6 \%)$. Hal tersebut merupakan peluang pasar bagi Bangsa Indonesia, bahkan daerah-daerah yang mempunyai perairan yang sesuai untuk komoditi tersebut, tak terkecuali Kabupaten Banggai Kepulauan.

Indonesia menargetkan produksi rumput laut pada tahun 2011 sebanyak 3 juta ton rumput laut kering, untuk memenuhi permintaan pasar dunia yang grafiknya terus menanjak. Data di kementerian kelautan dan perikanan mencatat tahun 2009 mencapai 2,57 juta ton, dan target tahun 2010 sekitar 2,7 juta ton rumput laut kering.( Farid Ma'ruf, 2010). 
Sulawesi Tengah (Sulteng) menetapkan rumput laut sebagai komoditas utama yang akan dikembangkan secara besar-besaran dalam lima tahun kedepan dengan perkiraan produksi tumbuh ratarata 28 persen lebih tiap tahun. Dinas kelautan dan perikanan Sulteng menetapkan target produksi rumput laut Sulteng akan naik dari sekitar 720 ribu ton pada tahun 2010 menjadi 920 ribu ton pada tahun 2011 atau tumbuh 28 persen lebih tiap tahun. Tahun 2009 Sulteng berada pada posisi ketiga penghasil rumput laut nasional dengan produksi 480 ribu ton lebih setelah Sulsel sebanyak 690 ribu ton dan NTT sebanyak 566 ribu ton lebih. Sedangkan pada tahun 2011 produksi rumput laut Sulteng saat menjadi daerah penghasil terbesar di Indonesia diprediksi mencapai 920 ribu ton.(Hasanuddin Atjo, 2010)

Kabupaten Banggai Kepulauan adalah daerah yang mempunyai potensi sumberdaya alam perikanan yang cukup beragam dan potensial. Kabupaten Banggai Kepulauan (Bangkep) bakal menjadi sentra produksi rumput laut terbesar disulawesi tengah, pasalnya tingkat ketersediaan lahan pengolahan rumput laut di Bangkep mencapai 12.031 hektar, dari jumlah itu pemanfaatan baru mencapai 4.425,26 hektar, dengan capaian produksi pada tahun 2009 sebesar 127.536 ton rumput laut kering. Dengan angka produksi sebesar itu, Bangkep menyumbang sekitar 26,57 persen dari total produksi rumput laut Sulawesi Tengah yang mencapai 480.000 ton.

Menurut data yang ada pada Asosiasi Rumput Laut Indonesia (ASRINDO) Kabupaten Banggai Kepulauan, pada tahun 2009 produksi rumput laut di daerah ini sebesar 10.628 ton lebih/bulan atau 127.536 ton/tahun. Kecamatan yang memiliki potensi produksi terbesar adalah Kecamatan Bokan Kepulauan sebesar 2.315 ton dan kedua disusul oleh kecamatan Liang 2.216 ton per bulan. Sementara kecamatan yang tingkat produksinya paling rendah adalah kecamatan Totikum dan Buko dengan jumlah produksi masing-masing perbulannya 540 ton dan 490 ton. Berikut disajikan data produksi per bulan petani rumput laut di Kecamatan Kabupaten Banggai Kepulauan tahun 2009 seperti pada tabel berikut :

Tabel 1 Produksi Rumput Laut di Kabupaten Banggai Kepulauan Tahun 2009

\begin{tabular}{llcc}
\hline N & Kecamatan & $\begin{array}{c}\text { Jumlah } \\
\text { Petani }\end{array}$ & $\begin{array}{c}\text { Produksi / } \\
\text { Bulan (Ton) }\end{array}$ \\
\hline 1. & Bulagi & 425 & 697 \\
2. & Bulagi selatan & 350 & 678 \\
3. & Liang & 1.818 & $\mathbf{2 . 2 1 6}$ \\
4. & Tinangkung & 265 & 980 \\
5. & Banggai & 565 & 1.103 \\
6. & Totikum & 300 & 540 \\
7. & Bokan & 1.937 & 2.315 \\
8. & Kepulauan & 855 & 1.609 \\
9. & Lo.Bangkurung & 445 & 490 \\
& Buko & & \\
\hline & Jumlah & 6.960 & 10.628 \\
\hline
\end{tabular}

Sumber : ASRINDO Kabupaten Banggai Kepulauan Tahun 2010

Pemanfaatan rumput laut yang begitu luas dalam banyak industri, ditandai dengan permintaan pasar yang relatif terus meningkat, jumlah petani dan lahan yang digunakan dalam budidaya rumput laut di Kabupaten Banggai Kepulauan terus bertambah, termasuk di Kecamatan Liang yang menjadi obyek penelitian ini.

Di Kecamatan Liang tersebut, budidaya rumput laut telah menjadi mata pencaharian pokok sebagian masyarakatnya. Dari 8.608 jiwa penduduknya yang tersebar di 15 desa pada tahun 2008, 1.818 jiwa penduduknya menggantungkan hidupnya sebagai petani rumput laut atau sekitar 21.11 persen.

Jenis rumput laut yang dibudidayakan di Kecamatan Liang adalah dari spesies Eucheuma cottonii. Upaya mengembangkan budidaya rumput laut Eucheuma cottonii perlu dilakukan untuk meningkatkan kuantitas dan kualitas komoditi tersebut yang selama ini sebagian besar masih dihasilkan dari panen rumput laut secara alami. Eucheuma cottonii merupakan spesies rumput laut yang banyak dibudidayakan di perairan Indonesia. 
Secara keseluruhan masyarakat pembudidaya rumput laut di Kecamatan Liang Kabupaten Banggai Kepuluan menerapkan metode tali bentangan apung (floating long line methode). Penggunaan metode ini sudah dikembangkan sejak awal budidaya rumput laut hingga saat ini, namun masalah yang seringkali dihadapi oleh pembudidaya rumput laut adalah rendahnya produksi yang dihasilkan. Rendahnya produksi selama ini diakibatkan terbatasnya faktor-faktor produksi yang dimiliki para petani. Keterbatasannya faktor-faktor tersebut, petani rumput laut menjadi terbatas pula dalam pemilikan unsur -unsur input produksi dalam budidaya rumput laut, termasuk jumlah bibit, pengoptimalan curahan tenaga kerja, jumlah tarikan, dan pengalaman berusaha. Tarikan atau luas lahan, biasa disebut juga tali ris, yaitu tali yang digunakan untuk mengikat dan menggantungkan bibit rumput laut. Satu tarikan biasanya merupakan satu bal tali yang tidak dibagi. Satu bal tali tersebut beratnya hampir mencapai $5 \mathrm{Kg}$ atau sekitar 100 meter. Keterbatasan dalam kepemilikan tarikan mengakibatkan kemampuan produksi mereka menjadi terbatas pula. Untuk itu, petani rumput laut mengatasinya dengan membuka lokasi budidaya keluar lokasi yang sudah ada dengan jarak tempuh yang cukup jauh. Hal tersebut dilakukan karena lokasi di sekitar perkampungan telah memiliki petani lain.

Dalam melakukan budidaya rumput laut para petani harus secara rutin memeriksa tanaman mereka agar dapat berkembang sebagaimana yang diharapkan. Disinilah mereka dituntut untuk memiliki tenaga kerja yang baik agar hasil yang didapatkan optimal. Biasanya petani rumput laut setiap hari mendatangi lokasi budidaya guna membersihkan kotoran -kotoran yang menempel pada tanaman rumput laut, pada pelampung, tali utama dan tali jangkar, maupun yang ada di perairan sekitarnya. Untuk itu, mereka dituntut untuk memiliki tenaga kerja yang lebih banyak guna menyelesaikan kegiatan
- kegiatan mereka. Berdasarkan uraian diatas maka penulis mengambil judul dalam penelitian ini adalah : " Faktor faktor yang mempengaruhi produksi dan pendapatan usahatani rumput laut di Kecamatan Liang Kabupaten Banggai Kepulauan.

\section{Perumusan masalah}

Rumusan masalah dalam penelitian ini adalah sebagai berikut :

1) Berapa besar pengaruh bibit, tenaga kerja, luas lahan, dan pengalaman terhadap produksi rumput laut di Kecamatan Liang Kabupaten Banggai Kepulauan?

2) Berapa besar pendapatan usahatani rumput laut di Kecamatan Liang Kabupaten Banggai Kepulauan?

\section{Tujuan Penelitian}

Tujuan yang ingin dicapai pada penelitian ini adalah :

1. Untuk mengetahui pengaruh bibit, tenaga kerja, luas lahan, dan pengalaman terhadap produksi rumput laut di Kecamatan Liang Kabupaten Banggai Kepulauan.

2. Untuk mengetahui seberapa besar pendapatan usahatani rumput laut di Kecamatan Liang Kabupaten Banggai Kepulauan.

\section{METODE PENELITIAN Jenis Penelitian}

Jenis penelitian yang digunakan adalah deksriptif-kausalitas, dimana penelitian deskriptif bertujuan untuk membuat deskripsi atau gambaran secara sistematis, faktual dan akurat mengenai fakta, sifat-sifat dan hubungan antara fenomena-fenomena yang diselidiki, tetapi tidak digunakan untuk membuat kesimpulan yang lebih luas atas data yang ada, sedangka penelitian kausalitas digunakan untuk menganalisis hubungan antara satu variabel dengan variabel lainnya atau bagaimana suatu variabel 
mempengaruhi variabel lainnya (Umar,2003).

Penelitian dilaksanakan dengan menggunakan metode studi kasus, yaitu suatu metode yang melakukan pengamatan atau penyelidikan yang kritis untuk memperoleh keterangan yang baik terhadap suatu persoalan tertentu di dalam daerah atau lokasi tertentu, dimana pada metode ini tidak semua individu dalam populasi diamati, melainkan hanya suatu bagian dari populasi, yang disebut contoh atau sampel pengamatan.

\section{Waktu dan Lokasi Penelitian}

Waktu penelitian dilaksanakan selama tiga bulan yaitu dari bulan Agustus, September, dan Oktober 2010, mencakup persiapan, pengumpulan data primer dan sekunder, serta pengolahan data sampai dengan menganalisis data.

Tempat penelitian ini dilaksanakan secara purposive, yaitu di tiga desa yaitu Desa Apal, Desa Boyomoute, dan Desa Popidolon di Kecamatan Liang, Kabupaten Banggai Kepulauan, Provinsi Sulawesi Tengah. Penelitian ini dilaksanakan di Kecamatan Liang karena didaerah ini musin tanam budidaya rumput laut terjadi sepanjang tahun, dan ketiga desa tersebut dipilih karena sebagian besar masyarakat didaerah tersebut melaksanakan usaha budidaya rumput laut, serta memiliki lahan yang cukup luas untuk budidaya rumput laut.

\section{Populasi dan Sampel}

Nazir ( 2003 ) menyatakan bahwa populasi adalah kumpulan dari ukuran ukuran tentang sesuatu yang ingin kita buat inferensi, dan populasi adalah berkenaan

dengan data, sementara unit - unit sampling adalah kumpulan dari unsur unsur populasi. Sampel adalah kumpulan dari unit sampling, yang ditarik biasanya dari sebuah frame, sedangkan sebuah frame adalah list atau urutan unit sampling yang tersedia.
Mengingat banyaknya petani rumput laut yang ada pada obyek penelitian dan diasumsikan populasi yang sifatnya homogen, maka teknik pengambilan sampel yang digunakan adalah tehnik proportional random sampling, yaitu dengan dihitung berdasarkan perbandingan, dalam hal ini perbandingan jumlah populasi pada objek yang diteliti. Besarnya jumlah sampel mempunyai peluang yang sama untuk dipilh, maka prosedur penentuan besarnya jumlah sampel dengan menggunakan rumus Slovin (Umar, 2003) :

$\mathrm{n}=\frac{\mathrm{N}}{1+\mathrm{N}(\mathrm{e})^{2}}$

Keterangan :

$\mathrm{n}=$ Jumlah sampel

$\mathrm{N}=$ Jumlah populasi

$\mathrm{e}=$ Presisi dengan batas simpangan toleransi $10 \%$

Dengan menggunakan tingkat presisi $10 \%$, maka ukuran sampel dalam penelitian ini :

$\mathrm{n} \equiv \frac{268}{1+268(0,10)^{2}}$

$\mathrm{n}=72,826=73$ petani

Sampel diambil dengan cara undian, dengan cara nama - nama petani rumput laut ditulis dan diambil secara acak pada obyek penelitian,yakni di tiga desa di Kecamatan Liang Kabupaten Banggai Kepulauan, Seperti pada tabel 2 berikut :

Tabel 2. Jumlah Sampel di Kecamatan Liang

\begin{tabular}{llcc}
\hline $\mathrm{N}$ & Nama Desa & $\begin{array}{c}\text { Populasi } \\
\text { (Petani) }\end{array}$ & Sampel \\
\hline 1 & Popidolon & 87 & $87 / 268 \times 73=24$ \\
2 & Boyomoute & 74 & $74 / 268 \times 73=20$ \\
3 & Apal & 107 & $107 / 268 \times 73=29$ \\
\hline \multicolumn{2}{r}{ Jumlah } & 268 & 73 \\
\hline \multicolumn{2}{c}{ Sumber $:$ Data }
\end{tabular}




\section{Analisis Data}

Data yang telah dikumpulkan baik yang berasal data primer maupun data sekunder, dipilah, dikategorikan dan diklasifikasikan sesuai dengan keterkaitan masing-masing data yang dibutuhkan, selanjutnya dilakukan analisis secara statistik. Adapun analisis yang dilakukan adalah : mengetahui pengaruh faktor-faktor bibit, tenaga kerja, luas lahan, dan pengalaman terhadap produksi rumput laut kering digunakan analisis Fungsi Produksi Cobb-Douglas (Soekartawi, 2003), dengan formula sebagai berikut :

$\mathbf{Y}=\boldsymbol{\beta}_{0} \sum_{i=1}^{n} \quad \mathbf{X}^{\beta} \mathrm{e}^{\mu}$

$Y=\beta o . X_{1}{ }^{\beta 1} . X_{2}{ }^{\beta 2} . X 3{ }^{\beta 3} . X 4{ }^{\beta 4} e^{\mu}$

Agar linier, persamaan (2)

ditransformasikan dalam bentuk logaritma natural (In), sehingga persamaan berubah menjadi :

$\operatorname{In} Y=\operatorname{In} \beta 0+\beta_{1} \operatorname{In} X_{1}+\beta_{2} \operatorname{In} X_{2}+\beta 3 \operatorname{In} X_{3}+\beta_{4} \operatorname{In} X_{4}+\mu$

Keterangan :

$\mathrm{Y}=$ Produksi Kering Rumput Laut

$\mathrm{X}_{1} \quad=$ Bibit (Rp)

$\mathrm{X}_{2} \quad=$ Tenaga kerja $(\mathrm{HOK})$

$\mathrm{X}_{3} \quad=$ Luas Lahan $\left(\mathrm{m}^{2}\right)$

$\mathrm{X}_{4} \quad=$ Pengalaman Berusaha (Tahun)

$\beta_{0}=$ Intersep

$\beta_{1}-\beta_{4}=$ Parameter Yang Ditaksir

Analisis pendapatan petani rumput laut, dengan rumus :

$$
\Pi=\text { TR-TC }
$$

Keterangan:

$\Pi \quad=$ Pendapatan

$\mathrm{TR}=$ Total Revenue (Penerimaan)

$\mathrm{TC}=\mathrm{FC}+\mathrm{VC}$ atau Biaya keseluruhan (Gaspersz, 2008).

\section{HASIL DAN PEMBAHASAN}

Fungsi produksi adalah hubungan fisik antara variabel yang dijelaskan (Y) dengan variabel yang menjelaskan $(\mathrm{X})$. Variabel yang dijelaskan berupa output ( pada kasus ini disebut dengan produksi rumput laut kering, dalam satuan kilogram ), sedangkan variabel yang menjelaskan berupa input produksi (misalnya bibit, tenaga kerja, luas lahan yang digunakan, dan pengalaman berusaha). Analisis faktor produksi rumput laut sering dilakukan guna mengetahui informasi tentang input produksi yang mampu memberikan pengaruh nyata terhadap produksi. Walaupun demikian, pada kenyataan, faktor - faktor yang mempengaruhi produksi rumput laut tidak hanya berasal dari keempat input produksi tersebut, akan tetapi juga dipengaruhi oleh input dan faktor produksi lain yang tidak dimasukan pada model produksi yang dibangun. Faktor produksi lain tersebut akan terakumulasi pada variabel residualnya atau error term $\left(\mu_{\mathrm{i}}\right)$, namun tidak dianalisis pada penelitian ini.

Secara spesifik, penelitian ini selanjutnya menganalisis faktor - faktor produksi yang dibangun dalam model persamaan Cobb-Douglas, yakni bibit $(\operatorname{InX})_{1}$, jumlah hari orang kerja (HOK) $\left(\operatorname{InX} X_{2}\right)$, luas lahan budidaya rumput laut $\left(\operatorname{InX} X_{3}\right)$, dan pengalaman $\left(\operatorname{InX}_{4}\right)$. Untuk lebih jelasnya hasil analisis data yang diperoleh disajikan pada tabel 3. Berikut ini : 
Tabel 3 : Hasil Perhitungan Koefisien Regresi , T-hitung, Probabilitas, Koefisien Determinasi

\begin{tabular}{|c|c|c|c|c|}
\hline Var Terikat $(Y)$ & Var. Bebas (X) & $\begin{array}{c}\text { Koef. } \\
\text { Regresi }\end{array}$ & T-Hitung & Probabilitas \\
\hline & Bibit $\left(\mathrm{X}_{1}\right)$ & 0,114 & 2,582 & 0,002 \\
\hline Produksi & Tenaga kerja $\left(\mathrm{X}_{2}\right)$ & 0,176 & 3,380 & 0,001 \\
\hline \multirow[t]{2}{*}{ Rumput Laut } & Luas lahan $\left(\mathrm{X}_{3}\right)$ & 0,447 & 5,790 & 0.000 \\
\hline & Pengalaman $\left(\mathrm{X}_{4}\right)$ & 0,093 & 1,227 & 0.224 \\
\hline \multirow{5}{*}{\multicolumn{2}{|c|}{$\begin{array}{l}\text { Intersep } \\
\text { Koefisien Determinasi }\left(R^{2}\right) \\
\text { Adj.Determinasi }\left(\mathrm{R}^{2} \mathrm{Adj}\right) \\
\text { F-Hitung }\end{array}$}} & & \multirow{5}{*}{\multicolumn{2}{|c|}{$\begin{array}{l}\mathrm{N}=73 \quad \mathrm{~K}=4 \alpha=0.01 \alpha= \\
0,05 \\
\text { Db }=(\mathrm{N}-1)-\mathrm{k}=68 \\
\text { F-tabel }=3.65 \\
\text { t-tabel }=2.383, \mathrm{t}-\text { tabel }= \\
1,980\end{array}$}} \\
\hline & & & & \\
\hline & & & & \\
\hline & & & & \\
\hline & & & & \\
\hline
\end{tabular}

Sumber : SPSS Release 17 dan diolah kembali, 2010

Berdasarkan hasil perhitungan dengan bantuan program SPSS, seperti terlihat pada tabel 5. Menghasilkan model persamaan sebagai berikut :

$\hat{Y}=1,436+0,114 X 1+0,176 X 2+0,447 X 3+0,093 X 4$

Persamaan regresi yang dihasilkan menunjukkan arah pengaruh positif beberapa variabel yang mempengaruhi produksi rumput laut kering ( $\mathrm{Y}$ ), baik variabel bibit $(\mathrm{X} 1)$, tenaga kerja $\left(\mathrm{X}_{2}\right)$, Variabel luas lahan $\left(\mathrm{X}_{3}\right)$, dan variabel pengalaman $\left(\mathrm{X}_{4}\right)$.

Tabel 3 Menunjukan bahwa seluruh variabel penjelas $X_{i}$ secara simultan (bersama - sama) terhadap variabel yang dijelaskan $\mathrm{Y}$ menunjukan pengaruh yang sangat nyata. Hal ini diperlihatkan oleh nilai probabilitas $\mathrm{p}=0,000<0,05(\alpha=$ $0,05)$ atau $\mathrm{F}_{\text {hitung }}=43,267>\mathrm{F}_{\text {tabel }}=$ 3,65 dengan $\mathrm{db}(4 ; 68)$ pada $\alpha=0,05$ membuktikan menolak hipotesis nol. Ini berarti bahwa bibit, tenaga kerja , luas lahan, dan pengalaman, secara bersama sama memberikan pengaruh yang sangat nyata terhadap jumlah produksi kering rumput laut.

$\begin{array}{clrr}\text { Hasil } & \text { analisis } & \text { regresi } & \text { ini } \\ \text { menunjukkan } & \text { bahwa jika bibit yang }\end{array}$
Koefisien adjustment determinasi $\left(\mathrm{R}^{2}\right)$ sebesar 0,701, hal ini menunjukan bahwa variasi produksi rumput laut kering (Y) dapat diterangkan oleh variabel bebas bibit $\left(\mathrm{X}_{1}\right)$, tenaga kerja $\left(\mathrm{X}_{2}\right)$, luas lahan $\left(\mathrm{X}_{3}\right)$, dan pengalaman berusaha $\left(\mathrm{X}_{4}\right)$ sebesar $70.10 \%$,

sedangkan 20,90 \% diterangkan oleh faktor lain yang tidak dimasukkan dalam model penelitian ini misalnya faktor iklim.

Pengaruh dari masing - masing faktor produksi terhadap produksi kering rumput laut ( Y) adalah sebagai berikut :

\section{Bibit}

Variabel bibit $\left(\mathrm{X}_{1}\right)$ berpengaruh sangat nyata terhadap produksi kering rumput laut di Kecamatan Liang dimana probabilitas $\mathrm{p}=0,002<0,01$ atau $\mathrm{t}_{\text {hitung }}=$ $2,582>\mathrm{t}$ tabel $=2,383$ pada taraf kepercayaan $99 \%$ uji dua arah. Besarnya pengaruh tersebut dapat ditunjukkan pada nilai koefisien regresi 0,114 , hal ini memberikan arti bahwa apabila variabel bibit $\left(X_{1}\right)$ mengalami kenaikan 1 persen maka akan mengalami pengaruh yang positif, yaitu kenaikan produksi rumput laut kering (Y) sebesar 0,114 persen, dengan asumsi variabel yang lain dianggap tetap.

dimiliki petani rumput laut mengalami peningkatan maka produksi rumput laut 
akan meningkat pula. Penambahan bibit akan meningkatkan jumlah populasi tanaman rumput laut, dengan bertambahnya jumlah populasi rumput laut, maka akan banyak pula produksi rumput laut yang mereka hasilkan.

Berdasarkan hasil penelitian di tiga desa di Kecamatan Liang luas lahan ratarata $6.035 \mathrm{~m}^{2}$ kebutuhan pemakaian bibit rata-rata sebanyak $904 \mathrm{~kg}$ dengan produksi kering rumput laut $748 \mathrm{~kg}$. Menurut Iswadi (2007) menyatakan : bahwa budidaya rumput laut dengan metode long line jumlah bibit yang dibutuhkan sebesar 3200 $\mathrm{kg}-4600 \mathrm{~kg}$ per ha $\left(10.000 \mathrm{~m}^{2}\right)$ areal budidaya, hasil panen basah yang siap untuk dikeringkan sebesar $22.400 \mathrm{~kg}$ $32.200 \mathrm{~kg}$, atau diperoleh hasil produksi panen kering rumput laut sebanyak 2.800 $\mathrm{kg}-4.025 \mathrm{~kg}$ (konversi dari basah menjadi kering $8: 1$ )

Berdasarkan keterangan ini dengan membandingkan luas lahan $10.000 \mathrm{~m}^{2}=$ $3200 \mathrm{~kg}$ bibit dan produksi $2800 \mathrm{~kg}$, maka dengan luas lahan $6.035 \mathrm{~m}^{2}$ seharusnya kebutuhan untuk pemakaian bibit sebesar $1.920 \mathrm{~kg}$ dengan produksi kering rumput laut sebanyak $1.680 \mathrm{~kg}$. Sehingga kebutuhan bibit petani budidaya rumput laut di Kecamatan Liang sangat diperlukan dan pemakaian bibit rumput laut sebanyak $1016 \mathrm{~kg}$ (1.920 - 904) atau sebesar Rp.2.540.000 ( 1.016 x Rp.2500), dengan penambahan bibit tersebut maka produksipun akan meningkat pula.

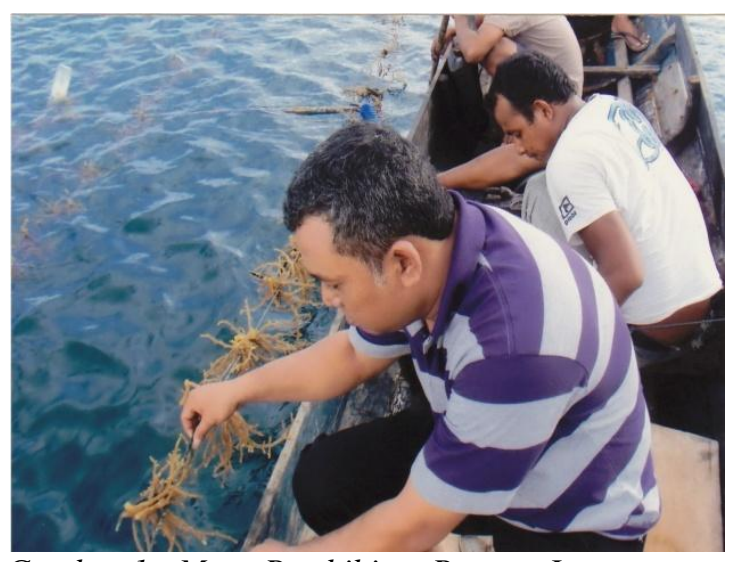

Gambar 1 : Masa Pembibitan Rumput Laut

\section{Tenaga Kerja (HOK)}

Variabel tenga kerja $\left(\mathrm{X}_{2}\right)$ berpengaruh sangat nyata terhadap produksi rumput laut kering di Kecamatan Liang, dimana probabilitas $\mathrm{p}=0,001<0,01$ atau $\mathrm{t}_{\text {hitung }}=$ $3,380>\mathrm{t}$ tabel $=2,383$ pada taraf kepercayaan $99 \%$ uji dua arah. Besarnya pengaruh tersebut dapat ditunjukkan pada nilai koefisien regresi sebesar 0,176 ,

hal ini memberikan arti bahwa apabila variabel tenaga kerja/HOK $\left(\mathrm{X}_{2}\right)$ mengalami kenaikan 1 persen maka akan mengalami pengaruh yang positif, yaitu kenaikan produksi rumput laut kering (Y) sebesar 0,176 persen, dengan asumsi variabel yang lain dianggap tetap.

Hasil analisis regresi ini menunjukkan bahwa pengaruh tenaga kerja sangat besar terhadap produksi rumput laut di Kecamatan Liang Kabupaten Banggai Kepulauan. Hal ini dikarenakan curahan/penggunaan tenaga kerja (HOK) dalam kegiatan budidaya rumput laut 
di Kecamatan Liang relatif kecil dan penggunaannya belum optimal, yaitu ratarata $18 \mathrm{HOK} / 6.035 \mathrm{~m}^{2} / \mathrm{MT}$.

Menurut Iswadi ( 2007 ) kebutuhan hari orang kerja $(\mathrm{HOK})$ dan jumlah pekerja untuk budidaya rumput laut dengan metode long line dengan luas lahan 10.000 $\mathrm{m}^{2}$ (1ha), seperti tertera pada tabel 4 berikut ini :

Tabel 4. Tahapan Pekerjaan Budidaya, Jumlah hari dan Pekerja Teknik Long Line, Luas Lahan $10,000 \mathrm{~m}^{2}$

\begin{tabular}{clc}
\hline NO & \multicolumn{1}{c}{ Tahapan } & \multicolumn{1}{c}{ Kebutuhan Hari Orang Kerja (HOK) } \\
\hline 1 & $\begin{array}{l}\text { Tahap penyiapan lahan, } \\
\text { pembersihan lahan, dan memasang } \\
\text { infrastruktur budidaya }\end{array}$ & 6 hari kerja, 10 pekerja \\
2 & $\begin{array}{l}\text { Memasang dan mengikat bibit pada } \\
\text { tali ris/utama dilahan budidaya }\end{array}$ & 4 hari kerja, 10 pekerja \\
3 & $\begin{array}{l}\text { Pemeliharaan, pengawasan, } \\
\text { penggantian bibit yang rusak atau } \\
\text { hilang }\end{array}$ \\
4 & $\begin{array}{l}\text { Masa panen dilakukan minimum 45 } \\
\text { hari setelah penyemaian } \\
\text { Pasca panen }\end{array}$ & 4 hari kerja, 8 pekerja \\
\multicolumn{1}{c|}{ Total HOK } & 2 hari kerja, 4 pekerja \\
\hline
\end{tabular}

\section{Sumber : Dit.Produksi.Ditjen Perikanan Budidaya DPK,2010}

Berdasarkan hasil penelitian ini usaha budidaya rumput laut diketiga desa di Kecamatan Liang dengan rata-rata 18 HOK/6.035 $\mathrm{m}^{2} / \mathrm{MT}$ perlu penambahan penggunaan tenaga kerja, dengan perbandingan luas lahan $10.000 \mathrm{~m}^{2}=36$ HOK, maka dengan luas lahan rata-rata $6.035 \mathrm{~m}^{2}$ penggunaan kebutuhan tenaga kerja sebanyak $22 \mathrm{HOK}$, sehingga perlu penambahan curahan tenaga kerja sebanyak 4 HOK, dengan penambahan ini berarti akan menyebabkan pelaksanaan kegiatan dalam usaha rumput laut akan terlaksana tepat sasaran dan tepat waktu misalnya pembibitan yang tepat, pemeliharaan yang tepat, pemanenan yang tepat dan lain - lain, yang akan cenderung meningkatkan produksi kering rumput laut. Tenaga kerja akan memperlancar dalam kegiatan operasional mulai dari pra panen, panen sehingga pasca panen. Faktor produksi tenaga kerja merupakan salah satu faktor produksi penting dan perlu di pertimbangkan dalam proses produksi dalam jumlah yang bukan saja dilihat dari ketersediaan tenaga kerja tetapi juga kualitas dan macam tenaga kerja perlu di perhitungkan (Soekartawi, 2003). Menurut Mubyarto (1986) setiap pengurangan tenaga kerja berarti pengurangan hasil produksi. Dengan demikian pengaruh tenaga kerja terhadap produksi pertanian sangat besar.

Tenaga kerja yang berasal dari keluarga pembudidaya ini merupakan sumbangan keluarga pada produksi rumput laut secara keseluruhan dan umumnya tidak dinilai dengan uang/upah. Pada saat tertentu pembudidaya membayar tenaga kerja tambahan misalnya dalam tahap pembuatan jangkar tanam yang membutuhkan tenaga yang lebih besar atau pun jumlah rumput laut yang diusahakan dalam jumlah besar pada setiap tahapan budidaya. Tenaga tambahan ini umumnya berasal dari tenaga kerja di sekitar lingkungan pembudidaya. Para pembudidaya mempunyai kelompok yang terdiri atas 15-25 orang. Diantara mereka dapat saling membantu bila membutuhkan tenaga tambahan pada unit usaha tani anggotanya. 


\section{Luas Lahan}

Variabel Luas lahan $\left(\mathrm{X}_{3}\right)$ berpengaruh sangat nyata terhadap produksi rumput laut kering di Kecamatan Liang, dimana probabilitas $\mathrm{p}=0,000<0,01$ pada taraf kepercayaan $99 \%$ atau $\mathrm{t}_{\text {hitung }}=$ $5,790>\mathrm{t}$ tabel $=2,383$ pada taraf kepercayaan $99 \%$ uji dua arah. Besarnya pengaruh tersebut dapat ditunjukkan pada nilai koefisien regresi 0,447 , hal ini memberikan arti bahwa apabila variabel luas lahan $\left(\mathrm{X}_{3}\right)$ mengalami kenaikan 1 persen maka akan mengalami pengaruh yang positif, yaitu kenaikan produksi rumput laut kering (Y) sebesar 0, 447 persen, dengan asumsi variabel yang lain dianggap tetap.

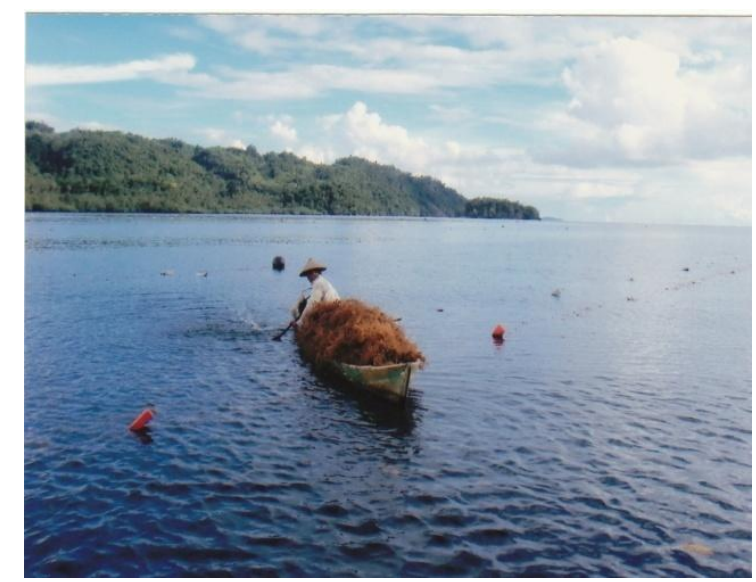

Gambar 2 : Lahan Budidaya Rumput Laut Di Desa Apal

Hasil analisis regresi ini menunjukkan bahwa jika luas lahan usaha budidaya rumput laut mengalami penambahan maka produksi rumput laut akan meningkat pula. Penambahan luas lahan usaha berarti akan meningkatkan jumlah populasi tanaman rumput laut, dengan bertambahnya jumlah populasi rumput laut cenderung akan meningkatkan produksi kering rumput laut dengan asumsi faktor produksi lain tercukupi. Hal ini dapat terjadi karena luas lahan usaha berupa pantai/lautan di Desa Apal, Popidolon, dan Boyomoute masih memungkinkan. Untuk dilakukan perluasan areal usaha rumput laut.

Hasil penelitian ini sesuai dengan penelitian terdahulu yang dilakukan oleh
Said (2009), bahwa variabel luas lahan berpengaruh sangat nyata terhadap produksi rumput laut, bahwa luas lahan yang dimiliki petani rumput laut mempunyai pengaruh utama untuk mengambil keputusan dalam pengelolaan usahataninya.

\section{Pengalaman Berusaha}

Variabel pengalaman berusaha $\left(\mathrm{X}_{4}\right)$ berpengaruh tidak nyata terhadap produksi kering rumput laut di Kecamatan Liang, dimana probabilitas $\mathrm{p}=0,224>0,05$ atau $\mathrm{t}_{\text {hitung }}=1,227<\mathrm{t}$ tabel $=1,980$ pada taraf kepercayaan $95 \%$ uji dua arah. Besarnya pengaruh tersebut dapat ditunjukkan pada nilai koefisien regresi 0,093, hal ini memberikan arti bahwa apabila variabel pengalaman $\left(\mathrm{X}_{4}\right)$ mengalami kenaikan 1 persen maka akan mengalami pengaruh yang positif, yaitu kenaikan produksi rumput laut kering (Y) sebesar 0,093 persen, dengan asumsi variabel yang lain dianggap tetap.

Hasil ini menunjukkan bahwa variabel pengalaman pengaruhnya sangat rendah terhadap produksi rumput laut kering di Kecamatan Liang Kabupaten Banggai Kepulauan. Sehinnga hal ini dapat diabaikan karena pengalaman berusaha berpengaruh tidak signifikan secara statistik.

\section{Pendapatan Petani Rumput Laut di Kecamatan Liang}

Pendapatan yang diterima petani rumput laut setiap panen tergantung pada banyaknya luas lahan dan jumlah tarikan yang dimiliki. Setiap tarikan rata-rata menghasilkan $20 \mathrm{~kg}$ rumput laut kering. Pendapatan tersebut setelah dikurangi biaya mulai dari pembelian bibit, upah kerja, bahan bakar dan lain-lain. Untuk lebih jelasnya pendapatan petani rumput laut di kecamatan Liang berdasarkan luas lahan yang dimiliki petani, seperti tertera dalam tabel berikut : 
Tabel 5. Analisis Pendapatan Rata-Rata Usahatani Rumput Laut Per Petani/6.035 m2/MT di Kecamatan Liang Kabupaten Banggai Kepulauan

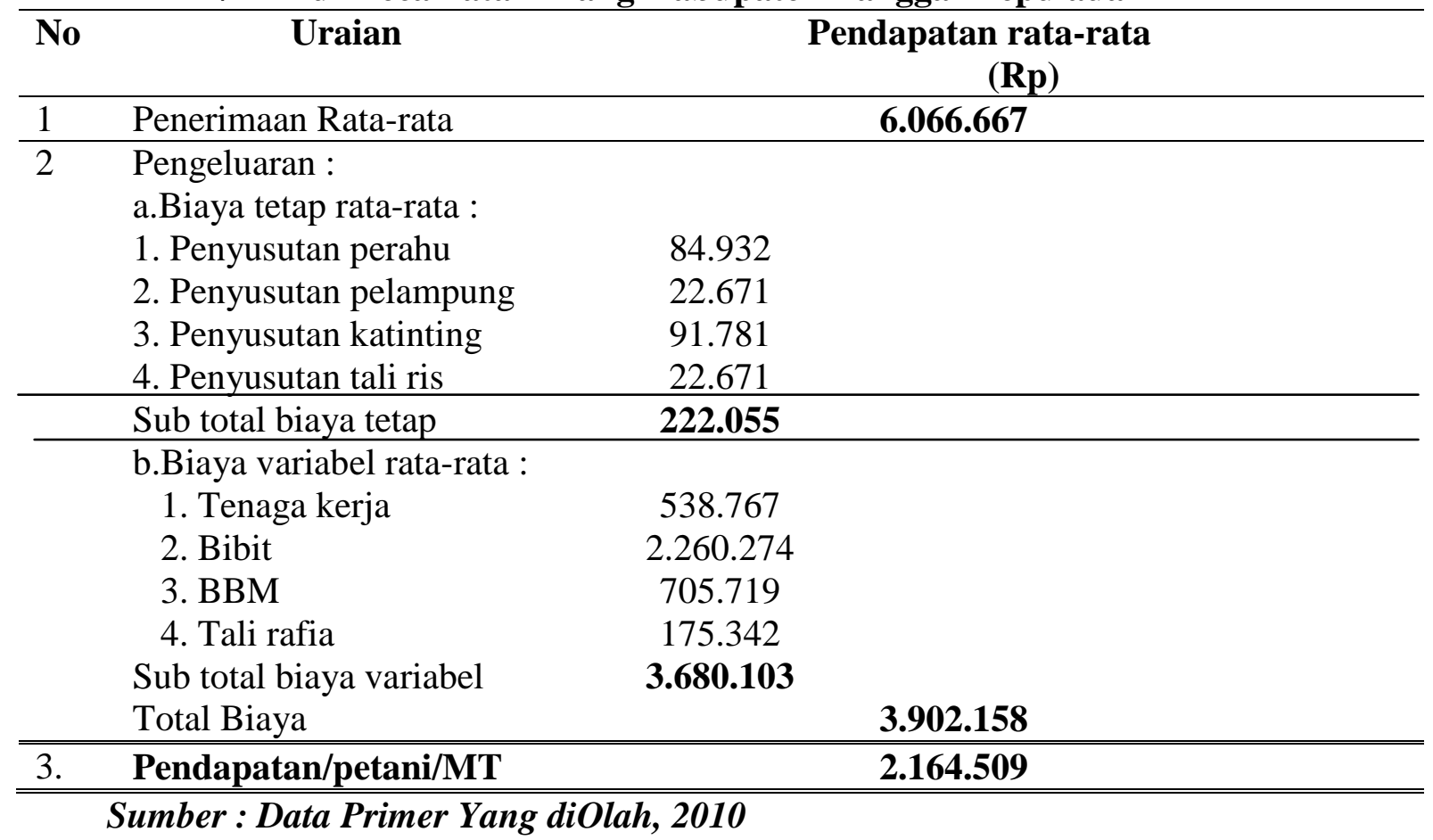

Tabel diatas menunjukkan pendapatan rata-rata petani rumput laut sebesar Rp. 2.164.509 per petani/6.035 m2/MT. untuk masa $6-8$ minggu ( 45 sampai 60 hari). Dengan pendapatan sebesar itu petani rumput laut di Kecamatan Liang, sudah cukup mampu untuk mencukupi kebutuhan keluarga petani rumput laut, serta memberikan kebahagian dan kesehjateraan bagi sebagian keluarga petani rumput laut. Sehingga diperlukan keseriusan dalam mengelola budidaya rumput laut, agar usaha budidaya rumput laut bagi para petani rumput laut di Kecamatan Liang sudah menjadi mata pencaharian pokok, dan bisa memberikan kebahagian dan kesejahteraan bagi mereka.

Di sinilah juga peran pemerintah dan swasta dibutuhkan agar bisa menjadikan komoditi rumput laut sebagai sumber pendapatan pokok masyarakat guna memperkuat fondasi ekonomi daerah di Kabupaten Banggai Kepulauan, khususnya di Kecamatan Liang. Hal tersebut membutuhkan waktu yang relative lama dan yang lebih penting dari itu, membutuhkan wawasan dan perlakuan baru terutama dari para penentu dan pelaksana kebijakan pemerintah. Diperlukan suatu paradigma baru dalam merumuskan konsep pemberdayaan petani rumput laut yang efektif dan efisien.

Secara teoritis, kita mengenal cukup banyak konsep pemberdayaan masyarakat, khususnya masyarakat pesisir seperti konsep pengembangan ekonomi masyarakat pesisir (PEMP), kemitraan , bapak angkat, inti-plasma dan sebagainya. Konsep - konsep ini telah diadopsi sedemikian rupa ke dalam berbagai program pemberdayaan ekonomi yang dilaksanakan pemerintah.

Konsep yang intinya adalah pengentasan kemiskinan tersebut dilakukan antara lain melalui pemberian bantuan peralatan seperti mesin katinting, tali dan lain - lain kepada masyarakat pesisir, termasuk petani rumput laut di dalamnya. Bantuan tersebut akan menambah modal petani rumput laut dalam melakukan kegiatan usahanya serta 
akan menambah mobilitas dan daya jangkau mereka dalam beraktivitas. Bantuan yang diberikan mempunyai paket yang sudah ditentukan dari atas dan cenderung seragam. Dengan model bantuan yang sifatnya top down ini mengakibatkan alat bantuan menjadi tidak efektif. Hal tersebut karena apa yang diberikan seringkali bukan merupakan kebutuhan petani rumput laut karena tanpa melalui diskusi dengan mereka. Banyak kasus dijumpai bahwa petani yang telah memiliki mesin katinting diberikan bantuan mesin katinting pula. Padahal yang petani rumput laut tersebut dibutuhkan adalah misalnya tali, baik tali utama maupun tali jangkar, bahkan dana segar untuk biaya operasional.

\section{KESIMPULAN DAN SARAN Kesimpulan}

Berdasarkan hasil uraian dan pembahasan pada bab terdahulu, maka dapat disimpulkan beberapa hal sebagai berikut :

1. Bahwa seluruh variabel bebas $X_{i}$ secara simultan (bersama - sama) terhadap variabel yang dijelaskan Y menunjukan pengaruh yang sangat nyata. Hal ini diperlihatkan oleh nilai probabilitas $\mathrm{p}=$ $0,000<0,05$ atau

$\mathrm{F}_{\text {hitung }}=43,267>\mathrm{F}_{\text {tabel }}=3,65$ dengan $\mathrm{db}(4 ; 68)$ pada $\alpha=0,05$ membuktikan menolak hipotesis nol. Ini berarti bahwa bibit, tenaga kerja (HOK), luas lahan, dan pengalaman, secara bersama - sama memberikan pengaruh yang sangat nyata terhadap jumlah produksi rumput laut kering. Secara parsial bibit $\left(\mathrm{X}_{1}\right)$, tenaga kerja/HOK $\left(\mathrm{X}_{2}\right)$ dan luas lahan $\left(\mathrm{X}_{3}\right)$ berpengaruh sangat nyata pada taraf kepercayaan $99 \%$ terhadap produksi rumput laut kering (Y), dari hasil ini dan penelitian terdahulu bahwa penambahan pemakaian bibit, pengoptimalan penggunaan tenaga kerja, dan perluasan lahan budidaya rumput laut dapat meningkatkan produksi rumput laut kering di Kecamatan Liang Kabupaten Banggai
Kepulauan. Variabel pengalaman $\left(\mathrm{X}_{4}\right)$ berpengaruh tidak nyata terhadap produksi kering rumput laut $(\mathrm{Y})$, dari hasil ini dan penelitian terdahulu bahwa pengalaman tidak dapat meningkatkan produksi rumput laut kering di Kecamatan Liang Kabupaten Banggai Kepulauan, sehingga variabel ini dapat diabaikan karena pengalaman berusaha berpengaruh tidak signifikan secara statistik.

2. Pendapatan rata - rata petani rumput laut kering per $6.035 \mathrm{~m}^{2} / \mathrm{MT}$ di Kecamatan Liang Kabupaten Banggai Kepulauan adalah sebesar Rp. 2.164.509 harga per $\mathrm{kg}$ sebesar Rp.8.000, dari hasil ini maka dapat disimpulkan bahwa pendapatan petani rumput laut dikecamatan Liang sudah bisa menjadikan budidaya rumput laut sebagai satu - satunya sumber pendapatan keluarganya. Sehingga kebutuhan hidup mereka akan terpenuhi dengan baik.

\section{Saran}

Berdasarkan kesimpulan hasil penelitian, maka disarankan hal-hal sebagai berikut :

1. Bagi pembudidaya rumput laut perlu menambah jumlah bibit dalam proses produksi, penambahan curahan tenaga kerja/HOK, meningkatkan etos kerja mereka, dan menambah luas lahan budidaya, guna meningkatkan produksi rumput laut di Kecamatan Liang Kabupaten Banggai Kepulauan.

2. Peningkatan atau penambahan modal harus diupayakan agar input produksi rumput laut dapat ditingkatkan melalui pembelian bibit, penggunaan tenaga kerja terampil, dan pembelian tali ris/utama.

3. Bagi peneliti selanjutnya agar lebih memperhatikan model faktor-faktor produksi lainnya yang tidak digunakan dalam penelitian ini, seperti : modal dan metode budidaya. 
DAFTAR PUSTAKA

Indriani, H, dan Sumiarsih, E., 1999. Budidaya Pengelolaan dan Pemasaran Rumput Laut. Penebar Swadaya, Jakarta.

Kolang, 1996. Panduan Budidaya dan Pengolahan Rumput Laut. Dinas Perikanan Sulawesi Utara, Manado.

Keppel, Charles Rene, 2008, Budidaya Rumput Laut di Pulau - pulau Kecil, MEP Unsrat Manado.

Mubarak, H.1999.Percobaan Penanaman Rumput laut Eucheuma Cotonii di Pulau Samaringa Kepulauan Menui.www.jasudanetberita8.com

Mubyarto, 1986. Pengantar Ekonomi Pertanian. LP3ES, Jakarta.

Mulyadi, 2007, Ekonomi kelautan, Edisi Pertama, Cetakan Kedua, Raja Grafindo Persada Jakarta.

Nazir, M, 2003, Metode Penelitian, Cetakan Kelima, Ghalia Indonesia, Jakarta.

Pramesti, G, 2007, Aplikasi SPSS 17.0 Dalam Model Linier Statistika, Elex Media Komputindo, Jakarta.

Soekartawi, 2002. Prinsip Dasar Ekonomi Pertanian : Teori dan Aplikasi, Edisi Kedua, Cetakan Keempat. PT. Raja Grafindo Persada, Jakarta, , 2003. Teori Produksi Dengan

Pokok Bahasan Analisis CobbDouglas. Jakarta. Raja Grafido Perkasa

Sudradjat, A.2009. Budidaya 23 Komoditas Laut Menguntungkan. Cetakan Kedua. Penebar Swadaya. Jakarta. Http://www.penebarswadaya.com

Sugiarto, 2000. Ekonomi Mikro Suatu Pendekatan Praktis. Pustaka Utama, Jakarta.Indonesia

Suratiyah. 2006, Pengantar Ekonomi Pertanian,Edisi Kedua, Erlangga Jakarta.
Tourino, P, Maryani, Kristiani, 2006. Budidaya Dan Pengolahan Rumput Laut. AgroMedia Pustaka. Jakarta.

Umar, H. 2003, Metode Penelitian Untuk Skripsi dan Tesis Bisnis, PT. Raja Grafindo Persada Jakarta.

Badan Pusat Statistik, 2009, Kecamatan Liang Dalam Angka, Kerjasama dengan Bappeda Kabupaten Banggai Kepulauan.

Amin, dkk.2005. Jurnal Pengkajian dan Pengembangan

Teknologi Pertanian.Hal 285.www.jasudanet.com

Danuri, R, 2003, Keanekaragaman Hayati Laut, PT. Gramedia Pustaka Umum Jakarta.

Farid, M.2010. RI Produsen Rumput Laut Terbesar, Jasuda.Net, Informasi Rumput Laut Indonesia.www.kabarbisnis.com

Noer, S.2009. Analisis Usaha rumput Laut (eucheuma sp) di Desa Kabalutan Kecamatan Walea Kepulauan Kabupaten Tojo Una-Una. Tesis tidak Diterbitkan. Program Pascasarjana Untad Palu.

Hasanuddin,A.2010. Rumput laut Komoditas Utama Kelautan Sulteng, .www.jasudanetberita8.com

Iswadi, 2007. Budidaya Rumput laut.Dit.Produksi,Ditjen Perikanan Budidaya,Dinas Kelautan dan Perikanan.www.dkp.co.id

Sujatmiko, dan Angkasa, 2007. Teknik budidaya rumput laut Dengan metode tali panjang. Laporan Hasil Penelitian Jakarta: Direktorat Kebijaksanaan Pengembangan dan Penerapan Teknologi II.BPPT. www.dkp.co.id 